\title{
MUHAMMADIYAH DAN PEMBERDAYAAN MASYARAKAT ISLAM
}

\author{
Ichwansyah Tampubolon \\ Fakultas dakwah dan Ilmu Komunikasi IAIN Padangsidimpuan \\ (ichwansyah.tampubolon@yahoo.com)
}

\begin{abstract}
In perspective of Islamic community empowerment, it can be rised the proposition that Muhammadiyah is really exist as an empowerment organization or development of the Islamic community in contemporary era. It is because of it's roles and contributions in effort autonomously and progressifly to conduct empowerment or development of the Islamic community in Indonesia, particularly in the area of religious life, education, health, and social by making use of modern Islamic management approach.

Key words: Muhammadiyah, Islamic community empowerment, mode of empowerment

Abstrak

Dalam perspektif pemberdayaan komunitas Islam, dapat dikemukakan dalil bahwa Muhammadiyah benar-benar ada sebagai organisasi pemberdayaan atau pengembangan komunitas Islam di era kontemporer. Itu karena peran dan kontribusi dalam upaya secara mandiri dan progresif untuk melakukan pemberdayaan atau pengembangan komunitas Islam di Indonesia, khususnya di bidang kehidupan agama, pendidikan, kesehatan, dan sosial dengan memanfaatkan pendekatan manajemen Islam modern.

Kata kunci: Muhammadiyah, pemberdayaan komunitas Islam, mode pemberdayaan
\end{abstract}




\section{A. Pendahuluan}

Di antara keunikan organisasi Muhammadiyah adalah aspek tampilannya yang beragam layaknya memiliki sejumlah wajah (multifaces). ${ }^{1}$ Secara teoritis, Muhammadiyah dapat dikategorikan sebagai organisasi gerakan tajdid atau gerakan reformis religius, gerakan Islam modern, gerakan dakwah amar ma`ruf nahi munkar, agen perubahan sosial, kekuatan politik, dan lain-lain. ${ }^{2}$ Tampaknya, keragaman teoritik yang muncul dalam memahami Muhammadiyah tidak terlepas dari kekayaan khazanah dan sepak terjang Muhammadiyah di berbagai bidang kehidupan melintasi berbagai zaman, di samping keragaman sudut pandang yang digunakan oleh para ilmuan dalam mengkajinya.

Dari perspektif pengembangan atau pemberdayaan masyarakat Islam, misalnya, tampaknya Muhammadiyah dapat pula diposisikan sebagai organisasi pengembang atau pemberdaya masyarakat Islam. Pernyataan ini setidaknya dapat dibuktikan berdasarkan atas peranan dan sumbangsihnya selama perjalanannya yang tetap eksis hingga di usianya yang ke-106 tahun dalam melakukan pembaharuan (tajdîd/modernisasi) kehidupan masyarakat Islam Indonesia di berbagai bidang kehidupan. Melalui gerakan aksi-praksisnya, Muhammadiyah terus berupaya mengentaskan masyarakat Islam dari berbagai persoalan keagamaan, sosial, moral, pendidikan, dan lain-lain. Pertanyaannya pokoknya adalah bagaimana pola pengembangan dan pemberdayaan masyarakat Islam yang dijalankan oleh Muhammadiyah?

\section{B. Pemberdayaan Masyarakat Model Muhammadiyah 1. Pengertian}

Secara etimologis, kata pemberdayaan (disebut juga dengan istilah pengembangan) berarti proses, cara, perbuatan memberdayakan. ${ }^{3}$ Sementara secara terminologis, terdapat sejumlah definisi tentang pemberdayaan atau pengembangan masyarakat (community empowerment/development), di antaranya adalah sebagai berikut:

a) Pengembangan masyarakat merupakan suatu proses dari satu tahapan ke tahapan berikutnya, sebuah metode untuk mencapai tujuan, sebuah prosedur

1 Mitsuo Nakamura, Bulan Sabit Muncul dari Balik Pohon Beringin: Studi tentang Pergerakan Muhammadiyah di Kota Gede, Penerjemah Yusron Asrafi, (Yogyakarta: Gajah Mada University Press, 1993), hlm. Xv. Alfian, Muhammadiyah: The Political Behaviour of Muslim Modernist Organization Under Dutch Colonialisme, (Yogyakarta: Gadjah Mada University Press, 1989), hlm. 88

${ }^{2}$ Musthafa Kamal Pasha dan Adabi Darban, Muhammadiyah sebagai Gerakan Islam dalam Perspektif Historis dan Ideologis, Yogyakarta: LPPI, 2003), hlm. 160

3 Pusat Bahasa Departemen Pendidikan dan Kebudayaan, Kamus Besar Bahasa Indonesia, (Jakarta: PT Gramedia Pustaka Utama, 2008), hlm. 300, 1071 
program dan sebagai sebuah gerakan menyapa orang dalam emosi dan keyakinan. ${ }^{4}$

b) Pengembangan masyarakat Islam adalah kerja-kerja sosial melalui usaha pemberdayaan secara sistematis dan terencana terhadap sumber-sumber daya yang dimiliki oleh masyarakat Islam secara partisipatif dan mandiri guna memperbaiki semua aspek kehidupannya secara lebih baik dan berkelanjutan. ${ }^{5}$

c) Pengembangan masyarakat adalah kegiatan peningkatan kesejahteraan manusia atau masyarakat sesuai dengan apa yang dirasakan dan dicita-citakan oleh masyarakat itu sendiri. ${ }^{6}$

d) Pemberdayaan masyarakat berarti aktivitas bagaimana orang-orang/masyarakat berusaha melakukan pengawasan terhadap kehidupan mereka sendiri dan berusaha untuk membentuk masa depan sesuai dengan kemampuan dan keinginan mereka sendiri. ${ }^{7}$

e) Pengembangan atau pemberdayaan masyarakat memiliki dua dimensi, yaitu: pemberdayaan sebagai proses dan pemberdayaan sebagai hasil. Sebagai proses pemberdayaan merupakan serangkaian aktivitas yang terorganisir dan ditujukan untuk meningkatkan kekuasaan/politik, kapasitas/kemampuan personal/interpersonal sehingga individu, keluarga, masyarakat mampu bertindak guna memperbaiki situasi-situasi yang mempengaruhi kehidupannya. Sebagai hasil, pemberdayaan atau pengembangan merupakan sebuah keadaan terwujudnya keberdayaan/keberkuasaan mencakup (a) mental/pikiran (state of mind), seperti perasaan berharga dan mampu mengontrol kehidupannya, (b) kekuasaan/kekuatan sosial (reallocation of power) melalui upaya modifikasi struktur sosial. Jadi pemberdayaan mencakup aspek peningkatan kemampuan secara individual atau komunal dan juga perubahan sistem dan struktur sosial, di bidang ekonomi (berupa peningkatan pendapatan), sosial-politik (mampu memperjuangkan aspirasi, berpartisipasi dalam kehidupan sosial, dapat memperoleh dan meningkatkan sumber-sumber daya dan mendapatkan pelayanan sosial. $^{8}$

Berdasarkan beberapa pengertian di atas, pengembangan masyarakat Islam model Muhammadiyah dapat dirumuskan sebagai proses atau hasil peningkatan kualitas hidup individu, komunitas dan masyarakat Islam, khususnya warga persyarikatan dan simpatisannya di berbagai bidang kehidupan secara terus-

\footnotetext{
${ }^{4}$ I.T. Sanders, Theories of Community Development. Rural Sociology 23(1) 1958: 1-12.

5 Abu Suhu, dkk., Islam Dakwah dan Kesejahteraan Sosial, (Yogyakarta: Fakultas Dakwah UIN Sunan Kalijaga, 2005), hlm. 27

6 Nasrul Effendy, Dasar-dasar Keperawatan Kesehatan Masyarakat, (Jakarta: EGC, 1998).

7 Isbandi Rukminto Adi, Pemberdayaan, Pengembangan Masyarakat dan Intervensi Komunitas, (Jakarta: Lembaga Penerbit Fakultas Ekonomi Universitas Indonesia, 2001), hlm. 33

${ }^{8}$ Zamah Sari, dkk., Kemuhammadiyahan, (Jakarta: UHAMKA Press, 2013), hlm. 341
} 
menerus dalam upaya meningkatkan kualitas kehidupan mereka menuju terwujudnya masyarakat Islam yang sebenar-benarnya. Jadi, pengembangan atau pemberdayaan masyarakat Islam sebagaimana yang dilakukan oleh Muhammadiyah dapat dimaknai tidak semata-semata dalam perspektif ekonomi, akan tetapi juga mencakup sudut pandang keyakinan keagamaan, sosiologis, politik, hukum, dan pemikiran.

\section{Muhammadiyah sebagai Organisasi Pemberdayaan Masyarakat Islam}

Muhammadiyah menggunakan istilah revitalisasi dalam hal pengembangan dan pemberdayaan masyarakat. Revitalisasi dimaknai sebagai upaya penguatan kembali, proses penataan, pemantapan, peningkatan, dan pengembangan masyarakat ke arah kemajuan di bidang keagamaan, pendidikan, kesehatan, dan kesejahteraan sosial. Artinya, Muhammadiyah berupaya menggerakkan dan mengoptimalisasi partisipasi aktif dan potensi masyarakat Muslim guna meningkatkan kualitas kehidupan sosial, ekonomi, dan lingkungan sosial mereka. ${ }^{9}$ Di satu sisi Muhammadiyah berperan secara aktif, progressif, dan simultan dalam upaya melakukan pengembangan masyarakat Islam, dan di sisi lain, masyarakat juga diharapkan dapat berperan sebagai subjek yang dapat mengambil alih tanggung jawab dan mengembangkan kemampuannya dan bahkan dapat menjadi penggerak masyarakat dalam melakukan aktivitas sosialkeagamaan atas kesadaran mereka sendiri secara komunal (organisasi) guna peningkatan kehidupannya di berbagai aspek kehidupan. Tujuannya adalah membebaskan masyarakat Islam dari keyakinan takhyul, khurafat dan bid ah serta kembali dalam semangat dan ajaran Islam yang murni, sehingga lahir masyarakat Islam yang maju dan sejahtera, berperadaban tinggi. ${ }^{10}$

Kalangan masyarakat yang menjadi sasaran peningkatan peran dalam pembangunan di bidang keagamaan, sosial, kesehatan, dan pendidikan itu mencakup:

a) Individu atau elit pimpinan atau pengurus lembaga secara vertikal maupun horizontal.

b) Warga atau keluarga Muhammadiyah, simpatisan, dan masyarakat umum di desa (kelurahan), kota, dan pemukiman khusus.

c) Kelompok masyarakat dengan kondisi dan kebutuhan khusus, seperti: anakanak yatim, fakir miskin, anak-anak sekolah, ibu hamil, lansia, dan lain-lain.

d) Organisasi otonom (ortom) yang secara langsung maupun tidak langsung dapat menyelenggarakan upaya-upaya kegiatan keagamaan, sosial, kesehatan, dan pendidikan, seperti: Ikatan Pelajar Muhammadiyah (IPM), Ikatan Mahasiswa

9 PP Muhammadiyah, Berita Resmi Muhammadiyah, (Yogyakarta: PP Muhammadiyah, 2010), hlm. 178-181.

${ }^{10}$ M.T. Arifin, Muhammadiyah Potret yang Berubah, (Surabaya: Institut Gelanggang Pemikiran Filsafat Sosial Budaya dan Kependidikan, 1996), hlm. 256 
Muhammadiyah (IMM), Pemuda Muhammadiyah (PM), Nasyiatul Aisyiyyah (NA), Aisyiah, Tapak Suci Muhammadiyah, Hizbul Wathan (HW), dan sebagainya.

Memberdayakan, memanfaatkan dan sekaligus meningkatkan sumber daya masyarakat secara terprogram dan berkelanjutan, Muhammadiyah menggunakan pendekatan organisasi. Dalam hal ini, Muhammadiyah melaksanakan sejumlah kegiatan resmi secara rutin dan berkesinambungan, meliputi: gerakan pengajian, pengelolaan masjid, kegiatan kaderisasi, pembinaan keluarga sakinah, gerakan jamaah dan dakwah jamaah, dan lain-lain. Pengembangan dan pemberdayaan masyarakat di bidang keyakinan, pemahaman, dan praktik ibadah, dilakukan melalui sejumlah gerakan pengajian, pengkajian, dan pelatihan keagaman. Misalnya, pengajian Ahad setelah sholat subuh di mesjid-mesjid Muhammadiyah diperuntukkan bagi kalangan masyarakat umum/umat Islam dan warga persyarikatan. Di samping itu, Muhammadiyah juga melakukan pengajianpengajian umum dalam kaitannya dengan acara-acara peringatan hari-hari besar Islam. Sementara pengajian (tabligh akbar), khusus bagi anggota dan simpatisan Muhammadiyah, dilakukan pada acara peringatan hari lahir Muhammadiyah pada setiap tanggal 18 November atau pada pengajian berkala yang biasanya dilakukan sekali tiga bulan di tingkat daerah Muhammadiyah. Dalam pada itu pengajian khusus bagi jajaran pimpinan Muhammadiyah dilakukan sekali dalam sebulan secara rutin. Pengajian-pengajian khusus dapat pula dalam bentuk pengajian tafsir, hadis, fiqh/ketarjihan, dan dirâsah islâmiyyah yang diperuntukkan bagi para kader, pimpinan, dan anggota persyarikatan guna peningkatan dan pendalaman pemahaman keislaman. Di samping itu, kegiatan "pengajian" dapat pula dilakukan dalam pelatihan-pelatihan keagamaan secara intensif, pengkajian-pengkajian keilmuan dalam bentuk seminar, simposium, kuliah umum, dan lain-lain termasuk pula pangkajian tentang isu-isu kontemporer yang berkembang secara nasional maupun internasional. Semua ragam kegiatan itu, direncanakan dan dilaksanakan secara resmi dengan memberdayakan para muballigh, panelis, ilmuan, dan lainlain dari kalangan Muhammadiyah maupun dari kalangan luar yang direkomendasikan memiliki kapasitas dan kemampuan.

Lalu, dalam bidang pendidikan dan kesehatan, Muhammadiyah memiliki potensi dan kiprah yang sangat berpengaruh terhadap upaya-upaya pengembangan dan pemberdayaan masyarakat. Guna pemberdayaan dan pengembangan sumber daya insani, misalnya, Muhammadiyah memberikan layanan pendidikan formal bagi peserta didik dari tingkat pendidikan dasar hingga pendidikan tinggi. Hingga akhir tahun 2014, Muhammadiyah memiliki 176 PT, 14346 TK-ABA-PAUD, 2604 SD/MI. 1772 SM/MTs, 1143 SMA/SMK/MA, 71 SLB, 102 Pondok pesantren, dan 15 Sekolah Luar Biasa. Sementara di bidang kesehatan dan pelayanan sosial, guna memberikan layanan kesehatan dan kehidupan sosial bagi masyarakat, Muhammadiyah mendirikan 457 rumah sakit dan rumah bersalin, 421 
panti asuhan, 82 panti bagi kalangan berkebutuhan khusus, 78 rumah asuh, 54 panti jompo, 1 panti untuk bayi-bayi terlantar, 38 santunan kematian, dan 15 BKPM. $^{11}$

Kegiatan pengembangan masyarakat juga dilakukan melalui kegiatan pengelolaan masjid. Masjid menjadi prasarana bagi kegiatan pembinaan aspek keruhanian jama`ah dan pembinaan manajemen mesjid sebagaimana tersebar di seluruh ranting Muhammadiyah. ${ }^{12}$ Kegiatan pembinaan keruhaniahan jama ah biasanya dilakukan melalui revitalisasi program-program pokok masjid secara rutin maupun berkala. Misalnya, kegiatan sholat berjama'ah, pelatihan imam masjid, khatib jum 'at, dan kuliah-kuliah singkat berupa kuliah tujuh menit (kultum) atau kuliah lima belas menit (kulibas). Sementara pembinaan aspek manajemen mesjid dilakukan melalui revitalisasi keorganisasian Badan Ta`mirul Masjid (BTM), peningkatan peran dan fungsi muballigh, sumber daya insani pengelola masjid, imam dan khatib, Remaja Mesjid, Taman Pengajian Alqur'an (TPA), dan lain-lain. Di samping itu pula, dilakukan revitalisasi pengelolaan dana, infrastruktur dan media untuk memakmurkan masjid.

Selanjutnya, secara internal, pengembangan masyarakat juga dilakukan melalui kegiatan kaderisasi. Kaderisasi anggota dan pimpinan Muhammadiyah dilakukan melalui dua model kaderisasi, yaitu: perkaderan tingkat dasar (disebut juga perkaderan utama) dan perkaderan fungsional. Pertama, perkaderan tingkat dasar (disebut juga perkaderan utama memiliki dua varian, yaitu: Darul Arqam dan Baitul Arqam. Model kaderisasi Darul Arqam menekankan kegiatan pendidikan dan pelatihan guna membentuk cara berfikir dan bersikap yang sama tentang Muhammadiyah sebagai gerakan Islam, gerakan dakwah, dan gerakan tajdid bagi setiap anggota dan pimpinan persyarikatan. Model perkaderan ini dilakukan minimal satu kali dalam setiap masa kepemimpinan. Sedangkan kaderisasi model Baitul Arqam merupakan perkaderan yang lebih sederhana dan khusus daripada model Darul Arqam. Kegiatannya dilaksanakan dua kali dalam satu periode kepemimpinan, khusus bagi kalangan pimpinan dan pengelola amal usaha Muhammadiyah dengan tujuan khusus sesuai dengan tuntutan dan kebutuhan tertentu. Kedua, perkaderan fungsional merupakan perkadferan dalam bentuk pelatihan, pendidikan, kursus, kajian intensif secara terstruktur, namun tidak memiliki standar baku kurikulum perkaderan. Tujuannya adalah untuk mencukupi kebutuhan tertentu dari majlis atau lembaga persyarikatan

11 Pimpinan Pusat Muhammadiyah, Laporan Pimpinan Pusat Muhammadiyah Periode 2010-2015, (Yogyakarta: Pimpinan Pusat Muhammadiyah, 2015), hlm. 23

${ }^{12}$ Terdapat 6.270 masjid dan 5.689 mushalla yang dimiliki oleh Muhammadiyah. Pimpinan Pusat Muhammadiyah, Laporan..., Ibid. 
Muhammadiyah. Misalnya, sekolah kader, pelatihan instruktur, pengajian pimpinan, pengajian khusus, pelatihan tata kelola amal usaha, dan diklat khusus. ${ }^{13}$

Lalu, pengembangan masyarakat di bidang keorganisasian juga dilakukan melalui gerakan dan kegiatan dakwah jama`ah, sebagaimana berlangsung di setiap jenjang dan tingkatan organisasi Muhammadiyah sejak dari tingkat pimpinan ranting, cabang, daerah, wilayah, dan pusat. Gerakan jama`ah dan dakwah jama`ah dilakukan oleh dan untuk jama`ah-jama`ah kecil berbasis jenis profesi dan pekerjaan, meliputi: pedagang, petani, nelayan, buruh, difabel, dan lain-lain. Dalam hal ini, organisasi berperan sebagai fasilitator dan pendamping bagi jama`ah-jama`ah kecil itu, khususnya bagi kalangan masyarakat miskin dan terpinggirkan guna memperjuangkan hak-hak mereka, mengadvokasi kebijakan publik, dan mengupayakan peningkatan taraf hidup mereka. Di bidang ekonomi, misalnya, melalui Majelis Ekonomi dan Kewirausahaan dilakukan kegiatan pembinaan dan pengembangan beberapa usaha mikro dan kecil dengan memanfaatkan lahan wakaf dan kerja sama dengan perusahaan dan lembaga keuangan di dalam dan di luar negeri. Di antaranya, usaha pembuatan bisnis kue di Bogor, rumah mode busana Muslim di Depok, usaha kuliner dan kerajinan di Tangerang, usaha produksi air dalam kemasan di Depok, Serang, Rembang, dan Cianjur, usaha bisnis ritel swalayan "Surya Mart" di jawa Timur dan ritel swalayan "Mentari" di Sumatera Barat, kegiatan Bina Ekonomi Keluarga (BUEKA) yang dikembangkan oleh Aisyiyah, koperasi dan Baitut Tamwil Muhammadiyah. Berbagai usaha lainnya yang bertujuan untuk meningkatkan kemampuan dan keterampilan berusaha juga terus dikembangkan untuk pemberdayaan dan pendampingan masyarakat, khususnya komunitas petani dan nelayan. Misalnya, pembinaan dan pelatihan tentang inovasi teknologi pertanian yang ramah lingkungan dengan pertanian pola organik dan pola pertanian terpadu. Dalam pada itu, kegiatan pemberdayaan juga dilakukan terhadap kalangan masyarakat marginal, seperti pendampingan terhadap komunitas abang becak di Yogyakarta, pendampingan pedagang asongan di Sleman, dan pendampingan terhadap kelompok pengrajin usaha mikro di Kokap Kulonprogo, di Patuk Gunung Kidul, dan lain-lain. Dalam hal ini juga, Muhammadiyah menjadikan ranting-rantingnya sebagai pusat-pusat koordinasi penanggulangan bencana dalam tahap tanggap darurat maupun tahap rehabilitasi. ${ }^{14}$

Dalam pada itu, di bidang pengembangan atau pemberdayaan kaum perempuan, kegiatan pengembangan masyarakat dilakukan melalui kegiatan pembinaan keluarga sebagaimana yang dikelola oleh organisasi otonom Aisyiah. Mereka memiliki peranan utama dalam hal pembinaan Keluarga Sakinah sebagai

13 Tim MPK PP Muhammadiyah, Sistem Perkaderan Muhammadiyah, (Yogyakarta: MPK Muhammadiyah, 2008), cet. ke-2, hlm. 60-65.

${ }^{14}$ Pimpinan Pusat Muhammadiyah, Laporan..., Op.Cit., hlm. 37-39 
bagian dari upaya untuk menciptakan atau melaksanakan program Qoryah Thayyibah. Guna mewujudkan masyarakat Muslim yang berkesetaraan dan berkeadilan gender, Aisyiyah melakukan kegiatan pelatihan-pelatihan, penyebaran tulisan-tulisan, menerbitkan buku-buku panduan, dan lain-lain. ${ }^{15}$ Aisyiyah juga memberikan pelayanan pendidikan secara formal dari tingkat pendidikan usia dini dan pendidikan tinggi. Ortom ini pada dasarnya fokus pada upaya-upaya pemberdayaan wanita di bidang pendidikan, kesehatan, dan sosial.

Kegiatan pengembangan masyarakat ini, secara internal, diamanahkan kepada Lembaga Pengembangan Cabang dan Ranting Muhammadiyah (LPCRM) di seluruh Indonesia. Secara internal, lembaga ini memiliki tiga misi utama. Pertama, melakukan pemekaran Pimpinan Cabang Muhammadiyah (PCM) hingga $70 \%$ dari seluruh kecamatan dan memekarkan Pimpinan Ranting Muhammadiyah (PRM) hingga 30\% dari seluruh desa di Indonesia. Kedua, melakukan pemberdayaan kepengurusan cabang dan ranting dengan bekerja sama dengan Pimpinan Daerah Muhammadiyah (PDM) dan Pimpinan Wilayah Muhammadiyah (PWM). Ketiga, menghidupkan kegiatan-kegiatan di tingkat cabang dan ranting bekerja sama dengan majelis-majelis dan lembaga-lembaga di lingkungan Muhammadiyah. Tujuannya adalah terciptanya kondisi dan perkembangan cabang dan ranting yang lebih kuat, dinamis, dan berkemajuan sesuai dengan prinsip dan cita-cita Muhammadiyah menuju terwujudnya masyarakat Islam yang sebenar-benarnya. ${ }^{16}$

Di antara strategi pengembangan cabang dan ranting itu adalah pemetaan kembali cabang dan ranting, pengingkatan kapasitas organisasi, diversivikasi kegiatan, mobilisasi generasi muda, dan memekarkan cabang dan ranting. ${ }^{17}$ Pemetaan itu penting dilakukan untuk memperoleh data terkini tentang situasi dan kondisi objektif cabang dan ranting di seluruh Indonesia guna memperoleh kelemahan dan potensi yang dimilikinya masing-masing. Berbasis data secara objektif itu lah kemudian dilakukan upaya-upaya revitalisasi kapasitas organisasi, pengkayaan kegiatan-kegiatan ranting menjadi lebih menarik, beragam, responsif, dan solutif bagi kebutuhan masyarakat setempat.

Dalam pada itu, guna memperkuat sistem gerakan dan jaringan, Muhammadiyah juga melaksanakan kerja sama dengan berbagai pihak, dari kalangan pemerintah, swasta, dan pihak luar negeri. Misalnya, kerja sama dengan Kementerian Lingkungan Hidup, Kesehatan, Hukum dan HAM, Mahkamah Konstitusi, Komisi Yudisial, ICMI dan lain-lain. Selain itu, Muhammadiyah juga

${ }^{15}$ Zamah Sari, dkk., Op.Cit., hlm. 231-232

${ }^{16}$ PP Muhammadiyah, Kebijakan Pelaksanaan Program Muhammadiyah Periode 20102015, (Yogyakarta: PP Muhammadiyah, 2010), hlm. 155.

${ }^{17}$ Ahmad Norma Permata, "Cabang dan Ranting sebagai Ujung Tombak, Inilah Agenda Mendesak Muhammadiyah”, hlm.4-6, sebagaimana dikutip dalam Zamah Sari, dkk., Ibid., hlm. 211 
berkerja sama dengan bank-bank syariah, seperti: Bank Syariah Bukopin, BSM, BMI, BRI Syariah, BNI Syariah, BTN Syariah, dan Bank Danamon Syariah. Kerja sama luar negeri antara lain dilakukan dengan pemerintahan Inggris, Australia, Salam World, San't Egidio, dan Asia Muslim Charity Foundation (AMCF).

Berdasarkan uraian di atas, dapat ditegaskan bahwa berbagai kegiatan pemberdayaan/pengembangan masyarakat yang dilakukan oleh Muhammadiyah mencakup berbagai aspek kehidupan, meliputi: pemberdayaan di bidang spiritualkeagamaan, pemberdayaan di bidang ekonomi-kemasyarakatan, ${ }^{18}$ pemberdayaan di bidang interaksi sosial-masyarakat, pemberdayaan di bidang sumber daya insani, pemberdayaan di bidang kerja sama dan jaringan dengan kekuatankekuatan sosial-budaya, ekonomi, politik, dan keamanan, dan pemberdayaan dan pengembangan masyarakat secara eksternal/umum melalui amal usaha-amal usaha Muhammadiyah dan amal usaha-amal usaha Aisyiyah di bidang pendidikan, kesehatan, dan sosial-kemasyarakatan. ${ }^{19}$

\section{Kekuatan dan Kelemahan Pengembangan Masyarakat Islam ala Muhammadiyah \\ a. Kekuatan}

Pengembangan masyarakat Islam model Muhammadiyah itu dilakukan secara sentralistik-organisatoris atas dasar hasil pengkajian ilmiah secara holistik dan multidisipliner. Dalam hal ini, Muhammadiyah menerapkan langkah-langkah strategis sebagai berikut.

Pertama, merumuskan masalah keummatan. Sejak masa pendiriannya, Muhammadiyah memandang dan memutuskan (biasanya melalui musyawarah di tingkat ranting, cabang, daerah, wilayah, dan pusat), setidaknya terdapat tiga masalah utama dan sangat mendasar yang dihadapi oleh umat Islam, yaitu: masalah sosial, masalah keagamaan, dan masalah moral. ${ }^{20}$ Masalah sosial mencakup kebodohan, kemiskinan, dan keterbelakangan. Dalam pandangan Muhammadiyah, umat Islam pada umumnya tidak terpelajar alias tidak memiliki pendidikan atau pengetahuan secara memadai dan seimbang, tidak terampil, dan tertinggal. Mereka, kalaupun memiliki pendidikan, pendidikannya bercorak klasik-tradisional sehingga mereka tidak mampu berfikir secara rasional dan tidak dapat bertindak secara kreatif, inovatif, progressif, dan kompetitif. Lalu, dalam pandangan Muhammadiyah, umat Islam lebih banyak berada di bawah garis

\footnotetext{
${ }^{18}$ Bandingkan Sudibyo Markus, "Model Pembinaan Jama`ah di Tingkat Ranting", dikutip dalam Zamah Sari, dkk., Op.Cit., hlm. 213.

19 diunduh Desember 2018

20 Ahmad Syafi'i Ma`arif, "Muhammadiyah: antara Praksisme dan Intelektualisme Islam", dalam M.A. Fattah Santoso dan Maryadi, Muhammadiyah Pemberdayaan Umat?, (Surakarta: Muhammadiyah University Press, 2000), hlm. 93-106, terutama hlm. 94.
} 
kemiskinan daripada tingkat sejahtera. Lalu, dari sisi kesehatan, Muhammadiyah memandang umat Islam banyak yang kurang gizi, sakit-sakitan, dan tidak memiliki fasilitas serta jaminan pengobatan dan kesehatan yang memadai.

Dalam hal kehidupan keagamaan, Muhammadiyah memandang terdapat persoalan pemahaman teologis/akidah yang menyimpang di kalangan masyarakat berupa keyakinan terhadap mitos-mitos (takhyul/khurafat) sehingga dipandang sangat potensial menggiring umat Islam kepada kemusyrikan. Umat Islam juga tidak sedikit yang beribadah secara bid `ah alias menambah-nambahi praktik ritual ibadah yang tidak berasal dari ajaran Alqur'an dan sunnah. Mereka larut dalam praktik-praktik keagamaan secara mekanistik-indivudualistik, namun miskin dalam aspek perilaku sosial atau aksi nyata secara religius-kemasyarakatan.

Sementara itu, dalam hal kehidupan moral, Muhammadiyah memandang dalam hal mengamalkan Islam, umat Islam kabur penglihatannya membedakan nilai-nilai kebaikan dan keburukan perilaku yang pantas dan tidak pantas menurut ukuran Alqur'an dan sunnah. Umat Islam dipandang mengalami masa-masa kegalauan dalam sistem nilai. Mereka lebih melirik nilai-nilai di luar ajaran Islam, akan tetapi lebih tertarik pada nilai-nilai non-Islam baik secara lokal maupun internasional.

Kedua, menetapkan program-program strategis secara berkesinambungan, progressif, dan kontekstual. Penetapan program-program strategis ini dirumuskan pada tingkat muktamar Muhammadiyah yang kemudian dijadikan keputusan yang mengikat seluruh jajaran organisasi alias ditanfizkan oleh Muhammadiyah. Dalam hal ini, Muhammadiyah memiliki "program jangka panjang" 20 tahun sejak tahun 2005 hingga 2025. Program jangka panjang tersebut kemudian dijabarkan pada setiap lima tahun sebagai program jangka menengah yaitu program (2005-2010), program (2010-2015), program (2015-2020), dan program (2020-2025). Artinya, berdasarkan sejumlah musyawarah resmi, berjenjang, dan berkala (sekali lima tahun kepemimpinan) Muhammadiyah menjabarkan sejumlah program tentang penataan dan pembinaan organisasi dan jaringannya secara internal, sistem gerakan dan amal usaha, peran Muhammadiyah dalam kehidupan ummat secara nasional dan internasional di berbagai bidang. ${ }^{21}$

Program-program itu, meminjam istilah Mezirow ${ }^{22}$, dapat diklasifikasikan, dalam tiga jenis program utama, yaitu: program integratif, program adaptif, dan program proyek. Program integratif merupakan program yang dilaksanakan oleh majelis-majelis dan lembaga-lembaga secara koordinatif, memerlukan bantuan teknis dan bahkan bantuan finansial secara besar-besaran dan melibatkan para pengurus dari tiap tingkatan pimpinan Muhammadiyah (pusat-daerah). Program-

\footnotetext{
${ }^{21}$ Pimpinan Pusat Muhammadiyah, Progam Muhammadiyah 2015-2020, (Yogyakarta: Pimpinan Pusat Muhammadiyah, 2015), hlm. 42-44

${ }^{22}$ Mezirow, Transformatif Dimension of Adult Learning, (New York: Suny Press, 1997).
} 
program integratif ini biasanya berkaitan dengan persoalan-persoalan keagamaan, pendidikan, pengkaderan, dan kesehatan. Sementara program adaptif hanya dijalankan oleh salah satu majlis/lembaga. Misalnya, Majlis Tabligh menyelenggarakan kegiatan tabligh atau kegiatan pengajian rutin di tingkat ranting, cabang, dan daerahnya masing-masing. Lalu, program proyek ditujukan terbatas untuk wilayah tertentu dan disesuaikan dengan kebutuhan daerah yang bersangkutan. Misalnya, program proyek pelatihan dan pembinaan imam, khatib, muballigh, dan pelaksana fardhu kifayah di ranting dan cabang Muhammadiyah, program proyek pelatihan manajemen bagi kalangan fungsionaris organisasi dan amal usaha-amal usaha, proyek pelatihan calon kepada madrasah/sekolah, dan lain-lain.

Ketiga, melaksanakan program berskala prioritas atas dasar komitmen bersama untuk melaksanakan amar ma`ruf nahi munkar. Semua program itu dilakukan melalui strategi power-coercive, yaitu berdasarkan pola relasi kekuasaan organisasi dan warga persyarikatan Muhammadiyah di setiap jenjang kepemimpinan Muhammadiyah. Dalam hal ini, Muhammadiyah memprioritaskan kelompok terpinggirkan (mustadh`afin) sebagai sasaran dan sekaligus mitra pengembangannya. Misalnya, berkaitan dengan kurang/lemahnya pemahaman keagamaan umat, Muhammadiyah melaksanakan kegiatan dakwah secara rutin dan berkala kepada dua macam masyarakat dakwah, yaitu: masyarakat dakwah dan masyarakat ijâbah. Masyarakat dakwah merupakan masyarakat yang belum mendapatkan pencerahan dan belum menjalankan ajaran Islam sebagaimana mestinya, meliputi: masyakat non-muslim dan masyarakat Muslim Abangan. Sedangkan masyarakat ijâbah adalah kelompok masyakarat yang telah menganut agama Islam dan juga mengamalkannya. Terhadap kedua kelompok ini, Muhammadiyah memberikan perlakuan dakwah yang relatif berbeda. Terhadap kelompok pertama, misalnya, diberikan materi-materi keimanan dan akhlak, sementara terhadap kelompok kedua di samping kedua materi itu diberikan materi-materi ibadah, muamalat, dan pengembangan umat dengan bobot materi yang lebih dalam dan luas guna meningkatkan kualitas kehidupan keagamaannya.

Keempat, menggunakan seluruh potensi dan sarana/prasarana yang dimilikinya secara organisatoris, meliputi: sumber daya insani, prasarana/sarana ibadah (mesjid, langgar/surau, dan lapangan terbuka), prasarana/sarana pendidikan (sekolah, pesantren, dan perguruan-perguruan tinggi), serta amal usaha-amal usaha lainnya (rumah-rumah sakit, rumah miskin, rumah yatim, pantipanti asuhan, dan lain-lain). Sementara sumber dananya berasal dari partisipasi anggota Muhammadiyah, para simpatisan, para donatur, dan terkadang dari bantuan pemerintah/ lembaga swasta selama hal itu didasarkan atas prinsip-prinsip suka-rela, halal, dan tidak mengikat.

Kelima, menerapkan tipe pengembangan masyarakat berpola production centered development dan people centered development. Tipe production centered 
development digunakan terhadap masyarakat tertinggal atau masyakarat dakwah yang dipandang sebagai komunitas berpengetahuan yang rendah sehingga untuk memajukannya diperlukan pengetahuan dari luar. Konsekuensinya, perencanaan program-programnya secara garis besar bersifat top-down, sentralistis, teknorat dan makro. Konsekuensinya, pimpinan pusat diposisikan sebagai pihak inisiator dan instruktur masyarakat, sementara masyarakat berposisi pasif dan kurang berani melakukan tindakan inisiatif dan kreativitas. Sedangkan model pengembangan bertipe people centered development dilakukan terhadap masyarakat ijâbah yang biasanya terdapat di kota-kota besar dengan cara melakukan optimalisasi pengetahuan (umum dan agama), partisipasi masyarakat (biasanya masyarakat urban/sub-urban), dengan cara memanfaatkan kekuatan organisasi dan kemajuan teknologi secara tepat guna. Perencanaannya dilakukan secara otonom berdasarkan kebutuhan lokal dan mikro sehingga masyarakat ijâbah memposisikan para pengurus Muhammadiyah hanya sebagai fasilitator. Dalam hal ini, warga persyarikatan dan simpatisan Muhammadiah, dapat berkreasi secara aktif-partisipatif, kreatif-inovatif, dan swadaya sesuai dengan sisuasi dan kondisi masyarakat setempat.

Keenam, melakukan monitoring dan evaluasi guna memantau proses dan hasil pelaksanaan program pengembangannya. Dalam hal ini, Muhammadiyah melalukan kegiatan monitoring melalui lembaga-lembaga organisasi sesuai dengan bidang kerjanya masing-masing. Kegiatan monitoring itu biasanya dilakukan oleh lembaga khusus yang dibentuk dan ditetapkan oleh Pimpinan Pusat Muhammadiyah.

Ketujuh, melakukan intervensi dengan memanfaatkan dinamika kehidupan warga persyarikatan dan simpatisan Muhammadiyah. Berdasarkan pengetahuan yang dimilikinya (boleh jadi juga dipengaruhi oleh sejarah, lingkungan sosial, kebudayaan, dan faktor-faktor individual) warga Muhammadiyah mengalami dinamika sesuai dengan responnya terhadap perkembangan zaman secara kritisadaptif. Model intervensi yang dilakukan oleh Muhammadiyah adalah melalui keputusan-keputusan organisasi-organisasi, pendampingan-pendampingan, dan bantuan-bantuan lainnya guna meningkatkan kualitas pemahaman keagamaan, pendidikan, kesehatan, dan kesejahteraan sosial.

Lalu, guna mengembangkan dan meningkatkan dinamika masyarakat Islam, khususnya warga Muhammadiyah, organisasi ini juga berupaya:

a) Menciptakan situasi dan kondisi yang kondusif agar potensi setiap ranting, cabang, daerah, dan wilayah Muhamnmadiyah dapat dikembangkan dan dimanfaatkan.

b) Mempertinggi mutu potensi yang ada melalui kegiatan pendidikan, pelatihan, kaderisasi di setiap tingkat amal-amal usaha yang dimiliki Muhammadiyah di bidang pendidikan, kesehatan, dan sosial-kemasyarakatan. 
c) Menjaga dan memelihara kelangsungan kegiatan Muhammadiyah yang sudah ada.

d) Meningkat kesejahteraan masyarakat Islam secara langsung maupun tidak langsung, secara internal maupun eksternal, setidak-tidaknya bagi masyarakat yang berdomisili di sekitar amal-amal usaha yang dimiliki oleh Muhammadiyah.

\section{b. Kelemahan}

Di balik kekuatan Muhammadiyah dalam hal pengembangan masyarakat Islam, secara paradoks, terdapat pula sejumlah kelemahan yang selalu membayanginya. Pertama, laju gerak Muhammadiyah menjadi lamban, tidak lincah, dan tidak gesit oleh karena segala perencanaan dan program kerja didasarkan atas keputusan Pimpimpinan Pusat Muhammadiyah secara sentralistikorganisatoris. Padahal, pada saat yang bersamaan di hadapan mereka menumpuknya sejumlah permasalahan yang sangat kompleks. Kedua, menguatnya ego sektoral dalam kegiatan pengembangan masyarakat sehingga distribusi tugas dan wewenang dalam Muhammadiyah secara vertikal (antarpimpinan ranting hingga pimpinan pusat) maupun horizontal (antarmajlis dan lembaga) yang semula ditujukan untuk memudahkan kerja organisasi dan melakukan sinergi secara koordinatif berubah menjadi "medan rebutan" kepentingan dan kepemilikan di kalangan pimpinan dan warga persyarikatan. Ketiga, munculnya kelompok yang memiliki sikap dan perilaku purufikatif versus kelompok yang mengedepankan sikap dan perilaku dinamis di kalangan internal Muhammadiyah dalam upaya mengembangkan program-program pemberdayaan masyarakat di bidang pemahaman, pemikiran, dan gerakan dakwah keagamaan. Sementara secara eksternal, ditengarai terdapat sikap dan perilaku intoleran terhadap kalangan Islam Abangan sehingga upaya-upaya pemberdayaan dan pengembangan terhadap mereka menjadi terhambat dan bahkan tidak jarang memperoleh penolakan atau setidak-tidaknya melahirkan sikap curiga dari kalangan mereka. Kelima, kurangnya kualitas dan kuantitas sumber daya manusia, khususnya di bidang sosial-keagamaan. Tanggung-jawab para penggiat urusan keagamaan sehari-hari di kalangan Muhammadiyah relatif sangat kurang, terutama dalam mengurus kegiatan-kegiatan rutin keagamaan, seperti: memakmurkan masjid/surau, pengajian-pengajian, kegiatan bimbingan masalah ibadah praktis, (seperti: sholat, urusan fardhu kifayah, khutbah, dan lain-lain). Keenam, budaya tata kelola organisasi yang baik (good governance) belum merata dan belum melembaga di semua amal usaha dan lembaga-lembaga di lingkungan persyarikatan Muhammadiyah. Prinsip-prinsip pertanggungjawaban secara akuntabel dan transparan secara internal maupun eksternal belum membudaya di lingkungan persyarikatan Muhammadiyah. Ketujuh, muncul fenomena penggerusan idologi dalam bermuhammadiyah. Mereka yang 
menduduki posisi-posisi strategis di amal-amal usahan dan jajaran pimpinan, khususnya, tidak jarang berkiprah di Muhammadiyah lebih mengedepankan kepentingan pribadi maupun kelompoknya masing-masing serta ideologi lain ke dalam Muhammadiyah, lari dari semangat dasar ideal bermuhammadiyah yaitu menggembirakan dakwah Islam dan memajukan amal-amal usahanya. ${ }^{23}$

\section{Penutup}

Dari penjelasan di atas, dapat dirumuskan bahwa kegiatan pengembangan dan pemberdayaan masyarakat Islam dilakukan dan diperjuangkan oleh Muhammadiyah berpola birokratik-organisatoris atas dasar konsensus dan komitmen bersama melaksanakan ajaran amar ma`ruf nahi munkar. Artinya, seluruh tingkat pimpinan organisasi, amal-amal usaha, organisasi otonom, dan anggotanya sama-sama berupaya untuk meningkatkan kemampuan dan martabat dirinya secara lahir dan batin guna mewujudkan masyarakat Islam yang sebenarbenarnya (baldatun thayyibatun wa rabbun ghafûr) secara progressif dan berkesinambungan. Dalam pada itu, secara internal hal itu juga bertujuan untuk menciptakan kondisi dan perkembangan warga persyarikatan yang lebih kuat, dinamis, dan berkemajuan sesui dengan prinsip dan cita-cita gerakan Muhammadiyah.

${ }^{23}$ Pimpinan Pusat Muhammadiyah, Laporan..., Op.Cit., hlm. 55-58. Bandingkan, Deni alAs`ari, Selamatkan Muhammadiyah Agenda Mendesak Warga Muhammadiyah, (T.Tpn.: Naufan Pusataka, 2010). 


\section{DAFTAR PUSTAKA}

Abu Suhu, dkk., Islam Dakwah dan Kesejahteraan Sosial. Yogyakarta: Fakultas Dakwah UIN Sunan Kalijaga, 2005.

Adi, Isbandi Rukminto. Pemberdayaan, Pengembangan Masyarakat dan Intervensi Komunitas. Jakarta: Lembaga Penerbit Fakultas Ekonomi Universitas Indonesia, 2001.

Al-As`ari, Deni Selamatkan Muhammadiyah Agenda Mendesak Warga Muhammadiyah. T.Tpn.: Naufan Pusataka, 2010.

Alfian. Muhammadiyah: The Political Behaviour of Muslim Modernist Organization Under Dutch Colonialisme. Yogyakarta: Gadjah Mada University Press, 1989.

Arifin, M.T. Muhammadiyah Potret yang Berubah. Surabaya: Institut Gelanggang Pemikiran Filsafat Sosial Budaya dan Kependidikan, 1996.

Effendy, Nasrul. Dasar-dasar Keperawatan Kesehatan Masyarakat. Jakarta: EGC, 1998.

Ma`arif, Ahmad Syafi'i. "Muhammadiyah: antara Praksisme dan Intelektualisme Islam", dalam M.A. Fattah Santoso dan Maryadi, Muhammadiyah Pemberdayaan Umat? Surakarta: Muhammadiyah University Press, 2000, hlm. 93-106.

Mezirow. Transformatif Dimension of Adult Learning. New York: Suny Press, 1997.

Nakamura, Mitsuo. Bulan Sabit Muncul dari Balik Pohon Beringin: Studi tentang Pergerakan Muhammadiyah di Kota Gede. Penerjemah Yusron Asrafi. Yogyakarta: Gajah Mada University Press, 1993.

Pasha, Musthafa Kamal dan Darban, Adabi. Muhammadiyah sebagai Gerakan Islam dalam Perspektif Historis dan Ideologis. Yogyakarta: LPPI, 2003.

Pimpinan Pusat Muhammadiyah, Laporan Pimpinan Pusat Muhammadiyah Periode 2010-2015. Yogyakarta: Pimpinan Pusat Muhammadiyah, 2015.

--------Program Muhammadiyah 2015-2020. Yogyakarta: Pimpinan Pusat Muhammadiyah, 2015.

-Berita Resmi Muhammadiyah. Yogyakarta: PP Muhammadiyah, 2010.

-Kebijakan Pelaksanaan Program Muhammadiyah Periode 2010-2015. Yogyakarta: PP Muhammadiyah, 2010.

Pusat Bahasa Departemen Pendidikan dan Kebudayaan, Kamus Besar Bahasa Indonesia. Jakarta: PT Gramedia Pustaka Utama, 2008.

Sanders, I.T. Theories of Community Development. Rural Sociology 23(1) 1958: $1-12$.

Sari, Zamah dkk. Kemuhammadiyahan. Jakarta: UHAMKA Press, 2013.

Tim MPK PP Muhammadiyah. Sistem Perkaderan Muhammadiyah. Yogyakarta: MPK Muhammadiyah, 2008.

diunduh Desember 2018 